\title{
Pharmacokinetics of amikacin in plasma of healthy goats after intravenous injection once daily for three days
}

\author{
Sania Naseem ${ }^{1}$, Mudasir Sultana ${ }^{1}$, Rajinder Raina ${ }^{1}$, Nrip Kishore Pankaj ${ }^{1}$, Pawan Kumar Verma ${ }^{1}$, \\ Nasir Ahmad Nasir ${ }^{1}$, Azad Ahmad Ahanger ${ }^{3}$, Shafiqur Rahman ${ }^{2}$, Shahid Prawez ${ }^{1, *}$ \\ Divisions of ${ }^{1}$ Pharmacology and Toxicology, and ${ }^{2}$ Veterinary Pathology, Faculty of Veterinary Sciences and \\ Animal Husbandry, SKUAST-J, R.S. Pura, Jammu-181 102 (J\&K), India \\ ${ }^{3}$ Division of Pharmacology and Toxicology, Faculty of Veterinary Sciences and Animal Husbandry, \\ SKUAST-Kashmir, Shuhama, Srinagar-190006, India \\ (Received: November 07, 2011; Revised: December 22, 2011; Accepted: December 23, 2011)
}

\begin{abstract}
Amikacin is a semisynthetic derivative of kanamycin and primarily active against aerobic Gramnegative-pathogens with limited activity against Gram-positive bacteria. Meager study was reported on pharmacokinetic data on multi-days administration of amikacin. Hence, pharmacokinetics study was done in five clinically healthy goats $(n=5)$, after intravenous bolus injection of amikacin sulfate at the dose rate of $10 \mathrm{mg} / \mathrm{kg}$ body weight daily for three consecutive days. The amikacin concentrations in plasma and pharmacokinetics-parameters were analyzed by using microbiological assay technique and noncompartmental open-model, respectively. The mean peak plasma concentrations (Mean \pm SD) of amikacin at time zero $\left(\mathrm{Cp}^{0}\right)$ was $114.19 \pm 20.78$ and $128.67 \pm 14.37 \mu \mathrm{g} / \mathrm{mL}$, on day 1 st and $3 \mathrm{rd}$, respectively. The mean elimination half-life $\left(\mathrm{t}_{1 / 2} \mathrm{ke}\right)$ was $1.00 \pm 0.28 \mathrm{~h}$ on day $1 \mathrm{st}$ and $1.22 \pm 0.29 \mathrm{~h}$ on day $3 \mathrm{rd}$. Mean of area under concentration-time curve $\left(\mathrm{AUC}_{0 \rightarrow \infty}\right)$ was $158.26 \pm 60.10$ and $159.70 \pm 22.74 \mu \mathrm{g} . \mathrm{h} / \mathrm{mL}$, on day 1 st and 3rd respectively. The total body clearance $\left(\mathrm{Cl}_{\mathrm{B}}\right)$ and volume of distribution at steady state (Vdss) on day 1 st and $3 \mathrm{rd}$ were $\mathrm{Cl}_{\mathrm{B}}=0.07 \pm 0.02$ and $0.06 \pm 0.01 \mathrm{~L} / \mathrm{h} . \mathrm{kg}$ and $\mathrm{Vdss}=0.10 \pm 0.03$ and $0.11 \pm$ $0.05 \mathrm{~L} / \mathrm{kg}$, respectively. No-significant difference was noted in both drug-plasma concentration and pharmacokinetics-parameters, respectively. Amikacin concentration in plasma was found higher up-to 4 $\mathrm{h}$ and $6 \mathrm{~h}$ onward on down-ward trends favour to reduce toxicity. Which also support the pharmacokineticpharmacodynamic way of dosing of aminoglycosides and hence, amikacin may be administered $10 \mathrm{mg} /$ kg intravenously daily to treat principally Gram-negative pathogens and limitedly Gram-positive-pathogens.
\end{abstract}

Keywords : amikacin, intravenous bolus injection, pharmacokinetics, three days, $10 \mathrm{mg} / \mathrm{kg}$

\section{Introduction}

Amikacin is a semisynthetic derivative of aminoglycoside kanamycin-A, with improved efficacy and not easily inactivated by aminoglycosedes inactivating enzyme [18]. Its antimicrobial activity is primarily against aerobic Gram-negative organisms of veterinary importance and limited activity against Gram-positive bacteria. To enhance antibacterial efficacy against Gram-positive bacteria and nullify the nephrotoxicity, synergistic combination of amikacin and beta-lactams were recommended [21]. Because of resistance developed against gentamicin and tobramycin against hospital pathogens, amikacin is a better armament [16].

To use amikacin judiciously, increase its efficacy, prevent resistance appearance and extend the postantibiotic, it is paramount importance to correlate pharmacokinetic and pharmacodynamic parameters. The pharmacokinetic (peak plasma concentration) and pharmacodynamic (MIC) parameters ratio $\left(\mathrm{C}_{\max }\right.$ : $\left.\mathrm{MIC}\right)$ equal to $8 \sim 10$ is required for better efficacy [13]. The pharmacokinetic study of amikacin was reported in several animal species such as cats [22], horses [15], buffalo calves [25], camel [26] and goats [3] primarily after single administration. Only meager data are available on multiple-days pharmacokinetics study of

\footnotetext{
*Corresponding author

Tel: +91-09419260687, Fax: +91-01923250639

E-mail: shahidprawez@gmail.com
} 
Table 1. Comparison of pharmacokinetic parameter on days 1 st and 3rd of amikacin sulfate after intravenous administration at dose rate of $10 \mathrm{mg} / \mathrm{kg}$ body weight

\begin{tabular}{cccc}
\hline \hline Pharmacokinetic parameters & $\begin{array}{c}\text { Day 1st } \\
(\mathrm{n}=5)\end{array}$ & $\begin{array}{c}\text { Day 3rd } \\
(\mathrm{n}=5)\end{array}$ & $\begin{array}{c}\text { Level of } \\
\text { significance }(95 \%)\end{array}$ \\
\hline $\mathrm{Cp}^{0}(\mu \mathrm{g} / \mathrm{mL})$ & $114.19 \pm 20.78$ & $128.67 \pm 14.37$ & NS \\
$\mathrm{Ke}(\mathrm{h})$ & $0.75 \pm 0.28$ & $0.67 \pm 0.13$ & $\mathrm{NS}$ \\
$\mathrm{t}_{1 / 2} \mathrm{ke}(\mathrm{h})$ & $1.00 \pm 0.28$ & $1.22 \pm 0.29$ & $\mathrm{NS}$ \\
$\mathrm{AUC}(0 \rightarrow \infty)$ & $159.70 \pm 22.74$ & $\mathrm{NS}$ \\
$\mathrm{Cl}_{\mathrm{B}}(\mathrm{L} / \mathrm{h} \cdot \mathrm{kg})$ & $158.26 \pm 60.10$ & $0.06 \pm 0.01$ & $\mathrm{NS}$ \\
$\mathrm{MRT}(\mathrm{h})$ & $0.07 \pm 0.02$ & $1.76 \pm 0.42$ & $\mathrm{NS}$ \\
$\mathrm{Vdss}(\mathrm{L} / \mathrm{kg})$ & $1.45 \pm 0.41$ & $0.11 \pm 0.05$ & $\mathrm{NS}$ \\
\hline
\end{tabular}

$\mathrm{Cp}^{0}$ : plasma drug concentration at time zero, Ke: elimination rate constant, $\mathrm{t}_{1 / 2} \mathrm{Ke}$ : elimination half-life, MRT: mean residence time, $\mathrm{Cl}_{\mathrm{B}}$ : total body clearance, $\mathrm{AUC}_{0 \rightarrow \infty}$ : total area under plasma drug concentration-time curve from ${ }_{0 \rightarrow \infty}$, Vdss: volume of distribution at steady state, NS: non-significant. All data are expressed as the mean $\pm \mathrm{SD}$.

amikacin, and needs to generate more scientific evidence. Therefore, the present study was intended with the objective to generate pharmacokinetics data after three days administration of amikacin and further to analyze the differences in concentration and pharmacokinetics parameters among day 1st and 3rd.

\section{Materials and Methods}

Five clinically healthy goats weighing $21 \sim 25 \mathrm{~kg}$ were procured from department of sheep husbandry, Jammu (India) and kept in departmental animal shed for about a month for the acclimatization. Animals were dewormed 15 days before the start of experiment and had $4 \sim 5$ daily hours grazing and limited pellet concentrate supplements with free-access to ad-libitum water. The drug Amee (German Remedies, India), containing 500 $\mathrm{mg}$ amikacin sulphate per $2 \mathrm{~mL}$ of solution. In each experimental goats $(n=5)$ drug amikacin was administered as intravenous bolus injection at the dose rate of $10 \mathrm{mg} /$ $\mathrm{kg}$ body weight daily for three consecutive days. The blood samples were collected from contra-lateral jugular vein other than drug injected vein in a sterile heperanized test tube at different predetermined time intervals at 5, 15, 30 and $45 \mathrm{~min}$ and 1, 1.5, 2, 3, 4, 6 , and $8 \mathrm{~h}$ on day $1 \mathrm{st}$ and $3 \mathrm{rd}$ day. The plasma of each samples were separated after centrifugation at $3000 \mathrm{rpm}$ for $10 \mathrm{~min}$ and kept in deep freeze at $-20^{\circ} \mathrm{C}$ till further analysis usually within three-days.

The amikacin-concentration in plasma of different goats $(\mathrm{n}=5)$, was analyzed by in vitro microbiological assay technique using Escherichia coli microbial type culture collection (MTCC) 739 as test organism [4]. The different concentrations of standard $(100,50,25,12.5$, $6.25,3.12$ and $1.56 \mu \mathrm{g} / \mathrm{mL}$ ) was prepared in normal plasma and triplicate of each concentration (standard/ samples) were poured within the five well made on a petri-dish. Each petri-dish containing $15 \mathrm{~mL}$ of antibiotic assay media No. 11 (HiMedia, India) and five wells were made in each. Before loading the samples/standards in wells, petri-dishes were seeded with Nephelometer [14] standardized Escherichia coli (MTCC) 739 in broth. The standard/samples were run in triplicate and lowerdetection limit of amikacin was $1 \mu \mathrm{g} / \mathrm{mL}$.

The concentrations of drug in the plasma of the samples were analyzed by first-order kinetics equation taking helps of regression coefficient equation of straight line [11]. The plasma concentration of the drug at time zero $\left(\mathrm{Cp}^{0}\right)$ was analyzed from same-equation of straight line. The different pharmacokinetics parameters were analyzed by a non-compartmental open-model based on statistical moment theory [11].

\section{Statistical analysis}

Statistical analysis, was done using one and two tailed $t$-test at $95 \%$ level of significance to compare the plasma-concentration of drug and pharmacokinetic parameters obtained on day 1st and 3rd [23].

\section{Results}

The mean peak plasma concentrations (Mean \pm SD) of amikacin at time zero $\left(\mathrm{Cp}^{0}\right)$ after intravenous bolus injection was $114.19 \pm 20.78$ and $128.67 \pm 14.37 \mu \mathrm{g} / \mathrm{mL}$, on day 1st and 3rd, respectively (Fig. 1 and Table 1). Correlation coefficient between concentration of drug 


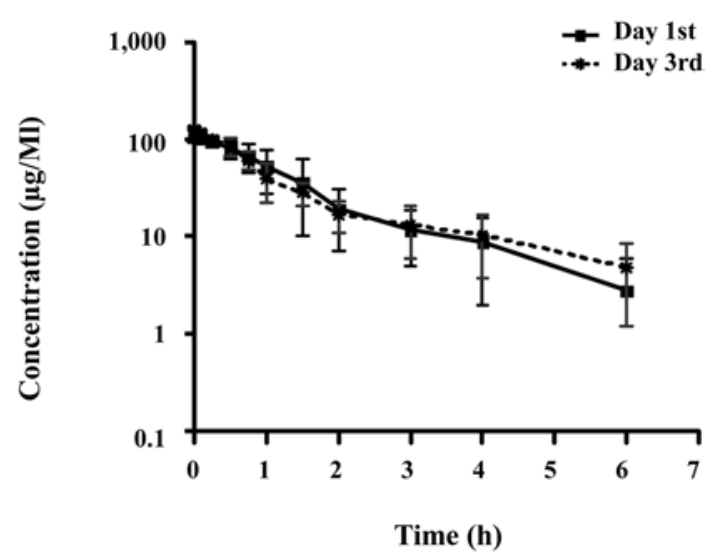

Fig. 1. Semi-logarithmic graph showing mean plasma concentration (Mean $\pm \mathrm{SD}$ ) of amikacin sulfate after intravenous bolus injection to healthy goats $(n=5)$ on day 1 st and 3rd.

and their respective zone of inhibition for standard was found $>98 \%$ and coefficient for intraday and inter-day assay was $<10 \%$. Amikacin-plasma concentration at different time 5, 15, 30 and $45 \mathrm{~min}$, also at 1, 1.5, 2, $3,4,6$ and $8 \mathrm{~h}$ were non-significantly differing on day $1 \mathrm{st}$ and 3rd (Fig. 1). The mean elimination half life ( $\mathrm{t}_{1 /}$ $\left.{ }_{2} \mathrm{ke}\right)$ was $1.00 \pm 0.28 \mathrm{~h}$ on day $1 \mathrm{st}$ and $1.22 \pm 0.29 \mathrm{~h}$ on day 3rd. Whereas area under concentration-time curve $\left(\mathrm{AUC}_{0 \rightarrow \infty}\right)$ was $158.26 \pm 60.10$ and $159.70 \pm 22.74 \mu \mathrm{g} . \mathrm{h} /$ $\mathrm{mL}$, on day $1 \mathrm{st}$ and $3 \mathrm{rd}$ respectively. The total body clearance $\left(\mathrm{Cl}_{\mathrm{B}}\right)$ and volume of distribution at steady state (Vdss) on day 1 st and $3 \mathrm{rd}$ were $\mathrm{Cl}_{\mathrm{B}}=0.07 \pm 0.02$ and $0.06 \pm 0.01 \mathrm{~L} / \mathrm{h} . \mathrm{kg}$ and $\mathrm{Vdss}=0.10 \pm 0.03$ and $0.11 \pm$ $0.05 \mathrm{~L} / \mathrm{kg}$, respectively. Pharmacokinetic parameters such as $\mathrm{Cp}^{0}$, ke, $\mathrm{t}_{1 / 2} \mathrm{ke}, \mathrm{AUC}_{0 \rightarrow \infty}, \mathrm{Cl}_{\mathrm{B}}$, MRT, Vdss were non-significantly differing on day 1 st and 3rd (Table 1).

\section{Discussion}

The mean plasma concentration of drug at all timeinterval was non-significantly differing on days 1 st and 3rd (Fig. 1). Mean of plasma drug concentration at time zero $\left(\mathrm{Cp}^{0}\right)$ was found non-significantly higher on day $3 \mathrm{rd}$ as compared to concentration on day 1 st. The higher concentration of drug is prerequisite to enhance killing effect, as the aminoglycosides are producing concentrationdependent killing-effect and also to reduce organ specific toxicity [19]. Saini and Srivastava [20] were reported the plasma drug concentration in bovine calves after single intravenous administration at $1 \mathrm{~min}$ was nearly similar to concentration at zero time $\left(\mathrm{Cp}^{0}\right)$ in the present study. Higher value of $\mathrm{Cp}^{0}$ was reported in horses after single intravenous injection at the same dose rate [17]. Therapeutic concentration of amikacin was maintained in plasma to $6 \mathrm{~h}$ in all five goats on both the days $1 \mathrm{st}$ and $3 \mathrm{rd}$. At time $8 \mathrm{~h}$ detectable concentration of the drug was found only in one goat on day 1st however in three goats on day $3 r d(n=5)$. The detectable concentration of the drug was found in more number of animals on day 3rd indicating after multiple days' therapy drug persisted in plasma for longer time-interval as compared to day 1st. No measurable plasma concentration of drug was noted after $8 \mathrm{~h}$ of drug administration and therefore meager possibility of drug accumulation in the kidney helps to combat toxicity [10]. The mean elimination half life $\left(t_{1 / 2} \mathrm{ke}\right)$ was non-significantly increased on day $3 \mathrm{rd}$ which is supported by slow total body clearance $\left(\mathrm{Cl}_{\mathrm{B}}\right)$ on day $3 \mathrm{rd}$ as compared to day 1 st. The elimination halflife $\left(\mathrm{t}_{1 / 2} \mathrm{ke}\right)$ was found nearly similar as in cows [24] after multiple-days intravenous and dogs [5] and horses [15] after single intravenous administration. Higher elimination half-life was reported in goats [1, 3], bovine-calves [20] and sheep [9] after single intramuscular administration. The total area under plasma drug concentration-time curve $\left(\mathrm{AUC}_{0 \rightarrow \infty}\right)$ was found no difference between days 1 st and 3rd. Nearly similar value of area under plasma drug concentration-time curve was reported in horses [15] and sheep [9] after its single i.v. administration at dose rate of $11 \mathrm{mg} / \mathrm{kg}$ and $7.5 \mathrm{mg} / \mathrm{kg}$, respectively. Where-as lower AUC value was reported in horses after single intravenous administration amikacin at dose rate of $10 \mathrm{mg} / \mathrm{kg}$ body weight [17]. Similar value of Vdss was also reported in cows [24] and cats [12] after multiday and single parenteral administration, respectively. Higher value of Vdss was reported in horses after single intravenous injection, at the dose rate of $10 \mathrm{mg} / \mathrm{kg}$ body weight [17].

Proper dosing-schedule of an antibiotic is very important for its judicious use, better efficacy along with low toxicity impact. Amino-glycosides are showing two phage of pathogen killing effect, in starting high concentration of drug is required followed by its post antibiotics effect [6]. Once-daily dosing of aminoglycosides is required to prevent nephrotoxicity [7]. For the concentration-dependent killing effect, pharmacokinetic and pharmacodynamics parameter such as maximum concentration of the drug $\left(\mathrm{C}_{\max }\right.$ or $\left.\mathrm{Cp}^{0}\right)$, minimum inhibitory concentration (MIC), respectively are taking 
part. If the ratio of $\mathrm{Cp}^{0}:$ MIC is in the range of $8 \sim 10$ or $6 \sim 10$ better antimicrobial killing effect reported [17]. The MIC value for amikacin against pathogens should be $\geq 4 \mu \mathrm{g} / \mathrm{mL}$ for Gram-negative pathogens infect the horses [2] and an average of $2.5 \mu \mathrm{g} / \mathrm{mL}$ for the fortytwo Gram-negative pathogens from birds [8]. The eighttimes $\mathrm{Cp}^{0}$ : MIC ratio value is equal to $32 \mu \mathrm{g} / \mathrm{mL}$ considering $\mathrm{MIC}=4 \mu \mathrm{g} / \mathrm{mL}$, and in the present study the eight-times value has maintained up to $1.5 \mathrm{~h}$ on day $1 \mathrm{st}$ and $1 \mathrm{~h}$ on day $3 \mathrm{rd}$. The drug is no doubt has remarkable potency against Gram-negative pathogens and showing limited activity against aerobic Gram-positive-bacteria such as Staphylococcus aureus.

\section{Conclusions}

In present study, concentration of drug was notsignificantly differs on day $3 \mathrm{rd}$ indicating at $10 \mathrm{mg} / \mathrm{kg}$ dose daily for three days in healthy goat may be sufficient to produce maximal-killing up-to $3 \mathrm{~h}$ of dosing and after $8 \mathrm{~h}$ onward there was no-detectable concentration of drug was found to produce toxicity although possibility of post-antibiotic effect still remain. Therefore, the drug amikacin may be used primarily to treat Gram-negative infections followed by limited use against Gram-positive infections in goats.

\section{Acknowledgments}

Thankful to Division of Pharmacology and Toxicology, FVSc. \&AH, RS Pura, Sher-e-Kashmir University of Agricultural Sciences and Technology-Jammu, Jammu ( $\mathrm{d} \& \mathrm{~K})$ for providing the infrastructure to furnish the research work.

\section{References}

1. Abo el-Sooud K. Pharmacokinetics of amikacin in lactating goats. J Vet Med A 1999, 46, 239-246.

2. Adamson PJ, Wilson WD, Hirsh DC, Baggot JD, Martin LD. Susceptibility of equine bacterial isolates to antimicrobial agents. Am J Vet Res 1985, 46, 447450.

3. Agrawal AK, Singh SD, Jayachandran C. Pharmacokinetics of amikacin in goats after single intramuscular administration. Indian J Pharmacol 2001, 33, 374-377.
4. Arret B, Johnson DP, Kirshbaum A. Outline of details for microbiological assay of antibiotics: Second revision. J Pharm Sci 1971, 60, 1689-1694.

5. Baggot JD, Ling GV, Chatfield RC. Clinical pharmacokinetics of amikacin in dogs. Am J Vet Res 1985, 46, 1793-1796.

6. Bartal C, Danon A, Schlaeffer F, Reisenberg K, Alkan M, Smoliakov R, Sidi A, Almog Y. Pharmacokinetic dosing of aminoglycosides; a controlled trial. Am J Med 2003, 114, 194-198.

7. Blaser J, König C. Once-daily dosing of aminoglycosides. Eur J Clin Microbiol Infect Dis 1995, 14, 1029-1038.

8. Bloomfield RB, Brooks D, Vulliet R. The pharmacokinetics of a single intramuscular dose of amikacin in red-tailed hawks (Buteo jamaicensis). J Zoo Wildl Med 1997, 28, 55-61.

9. Carli S, Montesissa C, Sonzogni O, Madonna M, Said-Faqi A. Comparative pharmacokinetics of amikacin sulphate in calves and sheep. Res Vet Sci 1990, 48, 231-234.

10. Contopoulos-Ioannidis DG, Giotis ND, Baliatsa DV, Ioannidis JP. Extended-interval aminoglycoside administration for children: a meta-analysis. Pediatrics 2004, 114, e111-118.

11. Gibaldi M, Perrier D. Pharmacokinetics. 2nd ed. pp. 409-424, Marcel Dekker, New York, 1982.

12. Jernigan AD, Wilson RC, Hatch RC. Pharmacokinetics of amikacin in cats. Am J Vet Res 1988, 49, 355-358.

13. Kashuba ADM, Nafziger AN, Drusano GL, Bertino JS Jr. Optimizing aminoglycoside therapy for nosocomial pneumonia caused by gram-negative bacteria. Antimicrob Agents Chemother 1999, 43, 623-629.

14. McFarland J. Nephelometer: an instrument for estimating the number of bacteria in suspensions used for calculating the opsonic index and for vaccines. J Am Med Assoc 1907, 14, 1176-1178.

15. Orsini JA, Soma LR, Rourke JE, Park M. Pharmacokinetics of amikacin in the horse following intravenous and intramuscular administration. $\mathrm{J}$ Vet Pharmacol Ther 1985, 8, 194-201.

16. Pien FD, Ho PW. Antimicrobial spectrum, pharmacology, adverse effects, and therapeutic use of amikacin sulfate. Am J Hosp Pharm 1981, 38, 981-989.

17. Pinto N, Schumacher J, Taintor J, Degraves F, Duran S, Boothe D. Pharmacokinetics of amikacin in 
plasma and selected body fluids of healthy horses after a single intravenous dose. Equine Vet J 2011, 43, 112116.

18. Ries K, Levison ME, Kaye D. In vitro evaluation of a new aminoglycoside derivative of kanamycin, BBKA: a comparison with tobramycin and gentamycin. Antimicrob Agents Chemother 1973, 3, 532-533.

19. Rybak MJ, Abate BJ, Kang SL, Ruffing MJ, Lerner SA, Drusano SL. Prospective evaluation of the effect of an aminoglycoside dosing regimen on rates of observed nephrotoxicity and ototoxicity. Antimicrob Agents Chemother 1999, 43, 1549-1555.

20. Saini SPS, Srivastava AK. The disposition kinetics, urinary excretion and dosage regimen of amikacin in cross-bred bovine calves. Vet Res Commun 1998, 22, 59-65.

21. Schlegel L, Sissia G, Fremaux A, Geslin P. In-vitro killing activity of combinations of $\beta$-lactam agents with aminoglycosides against penicillin-resistant pneumococci.
J Antimicrob Chemother 1997, 39, 95-98.

22. Shille VM, Brown MP, Gronwall R, Hock H. Amikacin sulfate in the cat: serum, urine and uterine tissue concentrations. Theriogenology 1985, 23, 829839.

23. Snedecor GW, Cochran WG. Statistical Methods. 6th ed. Iowa State University Press, Ames, 1967.

24. Sumano H, Gutierrez L, Velazquez C, Hayashida S. Pharmacokinetics and renal toxicity of three once-a-day doses of amikacin in cows. Acta Vet Hung 2005, 53, 231-240.

25. Uppal RP, Verma SP, Kumar V. Comparative pharmacokinetics of amikacin in buffalo calves following its intramuscular and subcutaneous administration. Indian Vet J 1998, 75, 262-264.

26. Wasfi IA, Abdel Hadi AA, Bashir AK, Alhadrami GA, Tanira MOM. Pharmacokinetics of amikacin in the camel. J Vet Pharmacol Ther 1999, 22, 62-64. 